\section{Harvest Maturity Affects Fruit Yield, Size, and Grade of Fresh-market Tomato Cultivars}

\author{
Jeanine M. Davis ${ }^{1}$ and Randolph G. Gardner ${ }^{2}$ \\ Department of Horticultural Science, North Carolina State University, Mountain \\ Horticultural Crops Research and Extension Center, 2016 Fanning Bridge \\ Road, Fletcher, NC 28732 \\ Additional index words. Lycopersicon esculentum, cultivars, postharvest physiology,
vine-ripe
}

\begin{abstract}
Eight staked, determinate tomato (Lycopersicon esculentum Mill.) cultivars were harvested when green (before breaker stage) or when pink (breaker stage and riper) in two replicated field studies. In general, total yield and average fruit size were reduced when fruit were harvested at the green stage. Harvest maturity had only a small effect on occurrence of most fruit defects, except fruit cracking, which was more severe for pink than for green fruit in the early season experiment. Although total yields for pink harvested fruit were higher than for green harvested fruit in the early season study, the high incidence of fruit crack in pink fruit resulted in similar yields of U.S. combination grade (U.S. no. 1 and U.S. no. 2) fruit for both treatments. Because the largest fruit often bring a premium price, harvesting fruit when pink probably will result in a higher price per kilogram than harvesting fruit when green. Fruit harvested green, however, are generally firmer, more crack resistant, and require fewer harvests than fruit harvested pink.
\end{abstract}

Vine-ripened tomatoes generally are considered to be of higher quality and have better flavor than fruit harvested mature green (MC) and ripened (Kavanagh et al., 1986; Picha, 1986; Stevens, 1986). Throughout the eastern United States, many staked fresh-market tomatoes are harvested at breaker (first pink on blossom end) or riper stages of maturity. In Florida, however, most growers harvest tomatoes at the MG stage (Sherman, 1988) because fruit are firmer and ship with less bruising and crushing than fruit harvested at the breaker stage (Kavanagh et al., 1986). In addition, harvesting costs are reduced because MG fruit require an average of two to three harvests (Sherman, 1988) compared to six to eight harvests for fruit showing pink (Stevens, 1986). Because of the success of Florida's MG-harvest tomato industry and in the interest of reducing costs and increasing profit margins, fresh-market tomato growers in other regions where tomatoes were traditionally harvested at the breaker or later color stages are now harvesting MG fruit (M.E. Lancaster, North Carolina Dept. of Agriculture, personal communication).

Maturity of a green tomato is difficult to

Received for publication 11 May 1993. Accepted for publication 22 Nov. 1993. This research was funded in part by the North Carolina Agricultural Research Service, Raleigh. We appreciate the partial support of this study by a grant from the North Carolina Tomato Growers Association. The cost of publishing this paper was defrayed in part by the paymentof page charges.Under postal regulations, this paper therefore must be hereby marked advertisement solely to indicate this fact.

Assistant Professor.

${ }^{2}$ Professor. determine without cutting the fruit and examining the interior (Kader et al., 1977; Sherman, 1988). In actual practice, most growers of socalled "mature-green" tomatoes wait until a small percentage of the fruit show pink, then all fruit on the first cluster, or all fruit meeting a minimum size requirement (usually $58 \mathrm{~mm}$ in diameter), or both are harvested (McLaurin et al., 1991; Sherman, 1988). As a result, a proportion of the harvested fruit are always immature (Kader et al., 1977; Kavanagh et al., 1986; Picha, 1986; Stevens, 1986), have an off-flavor, and are low quality when ripe (Kader et al., 1977; Kavanagh et al., 1986; Stevens, 1986). Because tomatoes continue to increase in size until color break, harvesting fruit when green results in smaller fruit than waiting until the breaker stage to harvest (Hayslip, 1979; Sayre et al., 1950).

In many fresh-market tomato production areas, determinate cultivars are transplanted to the field, pruned, staked, tied, trained to a string-weave system, and irrigated (Konsler and Gardner, 1990). In early studies on harvest maturity of tomatoes, indeterminate cultivars and other cultivars no longer produced commercially were used (Halsey and Jamison, 1950; Hayslip, 1979; Sayre et al., 1950). In addition, plants were direct-seeded (Taha et al., 1984) and grown without staking or pruning (Hayslip, 1979; Stoffella and Sherman, 1984), Sometimes the authors provided inadequate information for determining what cultural methods they used (Sayre et al., 1950). Our objective was to compare harvest at the so-called "mature-green" and the vine-ripe (breaker stage or riper) stages for eight determinate tomato cultivars currently grown in a staked production system.
'Flora-Dade', 'Sunny', 'Mountain Pride', 'Piedmont', 'Colonial', 'Summit', 'Mountain Delight', and the North Carolina breeding line NC 8267 (from here on referred to as a cultivar) were grown in two field experiments. All eight cultivars have a determinate growth habit and mature in mid- to late-season. These cultivars are used for production of tomatoes harvested at the vine-ripe and MG stages. Although the industry refers to fruit harvested when green as mature-green, we will refer to them as "green" because many of the fruit are not mature.

Two studies were conducted at the Mountain Horticultural Crops Research Station in Fletcher, N.C. For both tests a split-plot design was used with pink (breaker stage or riper) and green (before breaker stage) harvest stages as the main plots and cultivars as subplots. There were four replications. Subplots consisted of six plants spaced $0.6 \mathrm{~m}$ apart in the row with $1.5 \mathrm{~m}$ between rows. Plants were grown on bare ground, staked, and trained to the string-weave system (Konsler and Gardner, 1990). Axillary shoots were removed from the base of the plant up to, but not including, the one immediately below the first inflorescence. Soil was limed and fertilized according to soil test recommendations. Preplant $\mathrm{N}$ was applied at $73 \mathrm{~kg} \cdot \mathrm{ha}^{-1}$. Plots were sidedressed with $\mathrm{NH}_{4} \mathrm{NO}_{3}$ at $56 \mathrm{~kg} \mathrm{~N} / \mathrm{ha}$ one month after planting. Pest control practices, which included fungicide applications on a 5-day schedule, were applied according to recommendations for staked-tomato production in North Carolina (Konsler and Gardner, 1990). Overheadsprinkler irrigation provided $\approx 40 \mathrm{~mm}$ water/ week.

Plants were grown for 5 weeks in a soilless peat-vermiculite medium in a greenhouse in plastic flats with $5 \times 5 \times 6-\mathrm{cm}$ cells. Plants were transplanted to the field on 3 and 23 June for the early and late-season studies, respectively. For the early season experiment, pink fruit were harvested weekly for 6 weeks beginning 6 Aug. All fruit exhibiting any pink on the blossom end or more advanced signs of ripening were removed. For the late-season study, pink fruit were harvested weekly for 7 weeks beginning 29 Aug. Green harvests were closely patterned after what commercial growers of MC fruit use; therefore, the first green harvest occurred when $\approx 10 \%$ of the fruit on the first inflorescence of 'Flora-Dade' and 'Sunny' were at the breaker stage. Green fruit were harvested on 2, 11, and 21 Aug. for the early season study and on $28 \mathrm{Aug}$. and $12 \mathrm{Sept}$. for the late-season study. For the first green harvest, all fruit were removed from the first two inflorescences. In both studies, fruit $>63 \mathrm{~mm}$ in diameter were removed during the second green harvest. All fruit $>50 \mathrm{~mm}$ in diameter were removed for the third green harvest in the early season study. In the late-season study, insufficient fruit were left after the second green harvest to justify a third harvest.

Fruit were graded into U.S. combination (U.S. no. 1 and U.S. no. 2), U.S. no. 3, and culls. Fruit in U.S. combination grade were 
sized according to diameter (North Carolina Dept. of Agriculture, 1986) into medium (58$63 \mathrm{~mm})$, large $(6472 \mathrm{~mm})$, and extra large $(273 \mathrm{~mm})$. Fruit in the U.S. no. 3 and cull grades were sorted according to defects and weighed.

\section{Results and Discussion}

In the early season study, there was a cultivar $\times$ harvest maturity interaction for total yields (Table 1). In general, 'Colonial', NC 8267, and 'Summit' produced higher total yields than the other cultivars. The interaction occurred because 'Flora-Dade' produced similar green and pink yields. Relative to the other cultivars, however, 'Flora-Dade' produced a high total yield of green fruit but the lowest total yield of pink fruit.

Harvesting fruit pink increased total yields $16 \%$ and $19 \%$ over green-harvested fruit in the early and late-season studies, respectively (Table 1), primarily a result of pink fruit being heavier than green fruit (Table 1). In earlier studies with indeterminate tomato cultivars, harvesting green fruit caused more fruit set late in the season, and the resulting total yields were higher than when fruit were harvested at the vine-ripe stage (Halsey and Jamison, 1950; Sayre et al., 1950). When determinate tomatoes are harvested green, however, the harvest period generally is restricted to three harvests and completed in 34 weeks (Konsler and Gardner, 1990; McLaurin et al., 1991; Sherman, 1988). As a result, all fruit that will reach sufficient size and maturity for harvest within the 3-4 week period are set by the time the first green fruit are harvested. Hayslip (1979) reported increased fruit size with increasing fruit maturity with five tomato selections (three related to the determinate $<$ Walter') grown without staking or pruning. Although Sayre et al. (1950) reported higher yields from indeterminate cultivars harvested green instead of pink, they too found fruit weight increased with harvest maturity. Cultivar affected fruit weight in both of these studies. Average fruit weight was highest with 'Mountain Delight' and 'Summit' in the early season study and with 'Mountain Delight', Summit', and 'Piedmont' in the late-season study (Table 1).

Harvest maturity $\times$ cultivar interactions for percent extra large and large fruit occurred because 'Flora-Dade' had similar percentages of both size fruit regardless of harvest maturity (Table 2). This result contrasts with that for other cultivars that had higher percentages of extra-large fruit and lower percentages of large fruit when the tomatoes were harvested pink instead of green. 'Flora-Dade' was the earliest maturing (data not shown) and smallest-fruited cultivar in these studies. Therefore, because all cultivars were harvested on the same dates, green 'Flora-Dade' fruit were more mature and closer to their maximum size than green fruit from later-maturing cultivars. These results suggest that, to more accurately estimate MG fruit yields and fruit size in cultivars with a range of maturities, it may be necessary to harvest each cultivar at its time of optimum maturity to give the later-maturing cultivars time to reach maximum size before harvest.

Primary defects causing fruit to be graded U.S. no. 3 or cull for both harvest maturities were rough blossom scar, off-shape, and cracking (Table 3). In the late-season study, there was no difference in the incidence of rough blossom scar as a result of harvest maturity, probably because this defect is present at time of early fruit development. There was, however, a harvest maturity $\times$ cultivar interaction for incidence of rough blossom scar in the early season study. 'Flora-Dade' had 12\% rough blossom scar when harvested pink and $21 \%$ when harvested green. In contrast, 'Colo-

Table 1. Fruit yields and fruit weights of eight determinate tomato cultivars harvested at pink (breaker stage or riper) and green stage of maturity.

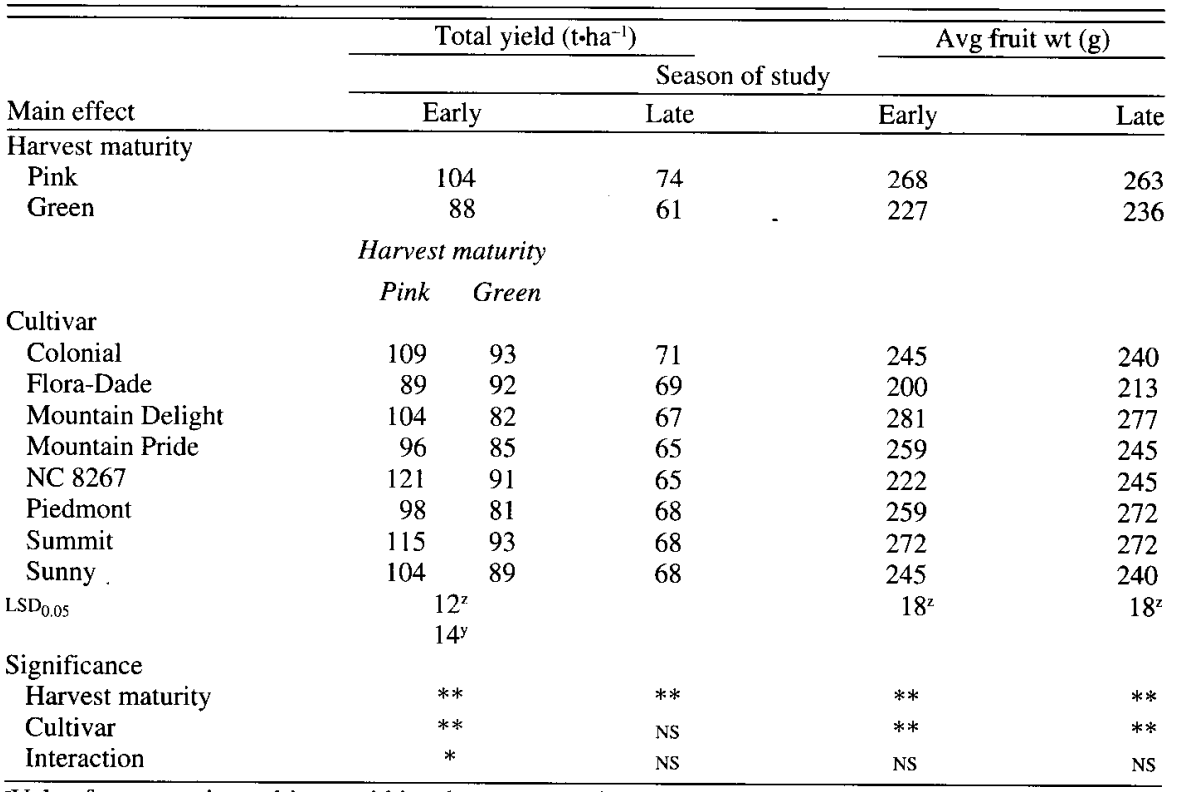

${ }^{2}$ Value for comparing cultivars within a harvest maturity.

${ }^{y}$ Value for comparing cultivars between harvest maturities.

ss, ${ }^{* * *}$ Nonsignificant or significant at $P \leq 0.05$ or 0.01 , respectively.

Table 2. Percentage of U.S. combination grade [extra large (EL; $\geq 73 \mathrm{~mm})$ and large $(\mathrm{L} ; 64-72 \mathrm{~mm})$ ] fruit of eight determinate tomato cultivars harvested at pink (breaker stage or riper) or green stages of maturity.

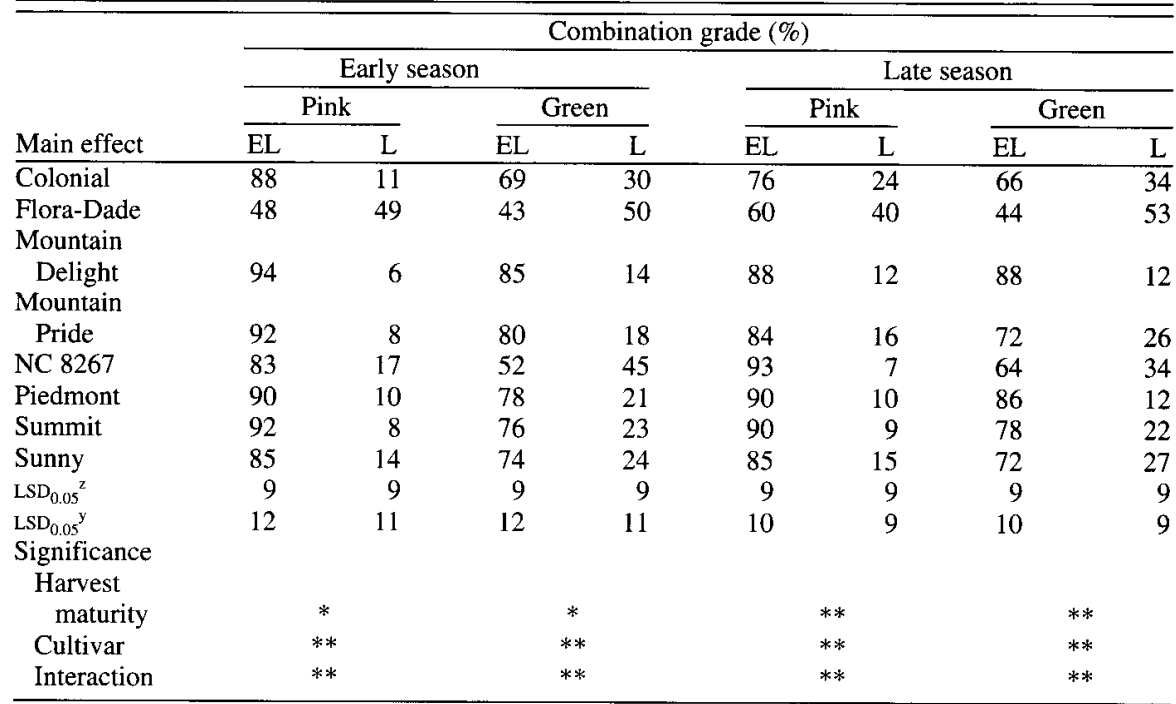

${ }^{2}$ Value for comparing cultivars within a harvest maturity.

yalue for comparing cultivars between harvest maturities.

*** Significant at $P \leq 0.05$ or 0.01 , respectively. nial' had $21 \%$ and $13 \%$ rough blossom scar hen harvested pink and green, respectively. eareas study, there also was a fruit harvested pink than in fruit harvested green. As reported previously (Halsey and Jamison, 1950), in the early season study, fruit than green (Table 3). In our study, atthough total yields were higher for fruit harested pink than for fruit harvested green Table 1), the high percentage of cracking in pint $\left.\cdot \mathrm{ha}^{-1}\right)$. In the late-season study, there was no 
Table 3. Fruit defects of eight determinate tomato cultivars harvested at pink (breaker stage or riper) and green stages of maturity.

\begin{tabular}{|c|c|c|c|c|c|c|}
\hline \multirow[b]{4}{*}{ Main effect } & \multicolumn{6}{|c|}{ Defects in total yield (\%) } \\
\hline & \multirow{2}{*}{\multicolumn{2}{|c|}{ Rough blossom }} & \multirow{2}{*}{\multicolumn{2}{|c|}{$\begin{array}{c}\text { Off-shape } \\
\text { Season of study }\end{array}$}} & \multicolumn{2}{|c|}{ Cracking } \\
\hline & & & & & & \\
\hline & $\overline{\text { Early }}$ & Late & Early & Late & Early & Late \\
\hline \multicolumn{7}{|l|}{ Harvest maturity } \\
\hline Pink & 18 & 25 & 32 & 42 & 31 & 20 \\
\hline Green & 19 & 22 & 27 & 40 & 3 & 10 \\
\hline \multicolumn{7}{|l|}{ Cultivar } \\
\hline Colonial & 17 & 22 & 31 & 41 & 21 & 22 \\
\hline Flora-Dade & 17 & 24 & 36 & 42 & 26 & 22 \\
\hline Mountain Delight & 18 & 20 & 21 & 36 & 10 & 9 \\
\hline Mountain Pride & 16 & 16 & 25 & 38 & 12 & 6 \\
\hline NC 8267 & 9 & 16 & 27 & 43 & 13 & 13 \\
\hline Piedmont & 22 & 26 & 26 & 41 & 10 & 3 \\
\hline Summit & 28 & 32 & 40 & 46 & 21 & 19 \\
\hline Sunny & 22 & 29 & 30 & 40 & 26 & 30 \\
\hline $\mathrm{LSD}_{0,05}$ & 5 & 5 & 6 & -.- & 7 & 8 \\
\hline \multicolumn{7}{|l|}{ Significance } \\
\hline Harvest maturity & NS & NS & $*$ & NS & $* *$ & NS \\
\hline Cultivar & $* *$ & $* *$ & ** & NS & $* *$ & ** \\
\hline Interaction & $*$ & NS & NS & NS & $* *$ & NS \\
\hline
\end{tabular}

Ns,*,**Nonsignificant or significant at $P \leq 0.05$ or 0.01 , respectively.

difference in the percentage of cracking between the pink- and green-harvested fruit; consequently, yields of U.S. combination grade fruit were higher for fruit harvested pink instead of green-53 and $41 \mathrm{t} \cdot \mathrm{ha}^{-1}$, respectively.

Differences in resistance to fruit cracking were evident among cultivars in both studies (Table 3). When harvested pink, 'Flora-Dade' and 'Sunny' had $46 \%$ and $41 \%$ cracked fruit, respectively. In contrast, 'Mountain Pride', 'Mountain Delight', and 'Piedmont' had the lowest percentages of cracked fruit regardless of harvest maturity (data not shown). The interaction between harvest maturity and cultivar in the early season study was due primarily to 'Summit', which had one of the highest percentages of cracking when harvested pink (41\%), but one of the lowest when harvested green $(1 \%)$. This result indicates the importance of using crack-resistant cultivars for harvesting pink fruit.

In contrast to indeterminate tomato cultivars (Halsey and Jamison, 1950; Sayre et al., 1950), total yields of the eight determinate cultivars tested were generally higher when fruit were harvested at the breaker or riper maturity stages compared to the green stage. Similar to other studies (Hayslip, 1979; Sayre et al., 1950), fruit were also larger when harvested pink instead of green. Often, a higher price is paid for extra-large than for large fruit (Davis, 1993), providing a possible economic advantage to allowing fruit to reach maximum size before harvesting. Because fruit size can increase appreciably just before color break (Hayslip, 1979), harvesting fruit at the breaker stage or later probably will result in a higher price per kilogram than for fruit harvested when green. Fruit harvested at the breaker stage may also have better quality in terms of color, flavor, sweetness, texture, and general acceptability compared to fruit harvested green (Kader et al., 1977; Kavanagh et al., 1986). Fruit harvested green, however, crack less, require fewer harvests, are generally firmer (Kavanagh et al., 1986), and are less susceptible to bruising (Sargent et al., 1992) than fruit harvested at the breaker stage. Because of the short season over which determinate tomatoes are harvested, increased late fruit set by removal of green fruit is not a factor in increasing yields.

\section{Literature Cited}

Davis, J.M. and E.A. Estes. 1993. Spacing and pruning affect growth, yield, and economic returnsof staked fresh-market tomatoes.J.Amer. Soc. Hort. Sci. 118:719-725.

Halsey, L.H. and F.S. Jamison. 1950. Yields of tomato varieties harvested at two stages of maturity from staked and unstaked plants. Proc. Amer.Soc. Hort. Sci. 56:332-336.

Hayslip,N.C. 1979, Fruit size increase as tomatoes approach maturity. Fort Pierce Agr. Res. Ctr. Res. Rpt. RL 1979-1.

Kader, A. A., M.A, Stevens, M. Albright-Holton, L.L.Morris, and M.Algazi. 1977. Effect of fruit ripenesswhenpickedon flavor and composition in fresh market tomatoes. J. Amer. Soc. Hort. Sci. 102:724-731.

Kavanagh, E.E., W.B. McGlasson, and R.L. McBride. 1986. Harvest maturity and acceptability of 'Flora-Dade' tomatoes, J. Amer.Soc. Hort.Sci. 111:78-82.

Konsler, T.R.andR.G. Gardner. 1990. Commercial production of staked tomatoes in North Carolina.Agr.Ext.Serv.,North Carolina State Univ., Publ.AG-405.

McLaurin,W.J.,D.M.Granberry,andW.O.Chance, 1991. Tomatoes. Coop. Ext. Serv., Univ. of Georgia, Circ. 484.

North Carolina Dept.of Agriculture. 1986. Tomato grade booklet. North Carolina Dept. of Agr.

Picha, D.H. 1986, Effect of harvest maturity on the finalfruitcompositionofcherryandlarge-fruited tomato cultivars, J. Amer. Soc. Hort. Sci. 111:723-727.

Sargent, S.A., J.K. Brecht, and J.J. Zoellner. 1992. Sensitivity of tomatoes at mature-green and breaker ripeness stages to internal bruising. J. Amer. Soc. Hort. Sci. 117:119-123.

Sayre, C. B., W.D. Pew, and M.E. Patterson. 1950. Comparativeyieldsoffivevarietiesof tomatoes harvested at mature-greenandatred-ripe maturity. Proc. Amer. Soc. Hort. Sci. 56:337-342.

Sherman, M. 1988, Harvesting and handling,p.1821.In:G.J.Hochmuth (ed,). Tomato production guide for Florida. Univ. of Florida, Coop. Ext. Serv., Circ. 98-C.

Stevens, M.A. 1986. The future of the field crop, p. 559-580. In:J.G.Atherton and J. Rudich (eds.). The tomato crop.Chapman and Hall,NewYork.

Stoffella, P.J. and M, Sherman. 1984. Semi-mechanicallyharvestedfresh-market tomato yields as influenced by harvest date and cultivar.HortScience 19:679-681.

Taha, A. A., M.S.Hassan,andA.Y. Ali. 1984. Effect of sowing date and stage of maturity at harvest on yield and quality of tomato for export. Acts Hort.143:533-538. 